\title{
GROWTH AND SURVIVAL OF ESCHERICHIA COLI CARRYING MULTIDRUG RESISTANCE PLASMIDS DURING PREPARATION AND STORAGE OF YOGHURT WITH REFERENCE TO THEIR PUBLIC HEALTH HAZARD
}

\author{
Abd El-Hafeez, M. M. and Amal A. Abd El-Haleem \\ Animal Health Research Institute, Assiut Regional Laboratory
}

\begin{abstract}
:
Through an investigation of bovine subclinical mastitic milk samples, E.coli strains were isolated and biochemically identified, they were untypable after testing against available nine serotypes. $E$. coli isolates were subjected to antimicrobial susceptibility testing against 13 antimicrobial agents (cefobid, ofluxacillin, claforan, streptomycin, spiramycin, cephradin, cloxacillin, ampicillin, unasyn, amoxycillin, penicillin G, ciprocin and polymexin B.sulphate). Plasmid profile analysis was carried out to 10 multidrug resistance E.coli strains, of which, only four isolates were carrying different plasmids with molecular sizes $(5.3-7.5 \mathrm{~kb})$. An E.coli strain carrying four plasmids was selected to be inoculated into sterile milk $\left(\mathrm{pH}\right.$ 6.6) with initial dose of $1.3 \times 10^{7}$ cells $/ \mathrm{ml}$ after adding the yoghurt starter cultures and incubation at $37 \pm 1^{\circ} \mathrm{C}$. In the finish product, E.coli count was $3.2 \times 10^{6}$ and the $\mathrm{pH}$ was 5.24. The yoghurt with its control were stored at $4 \pm 1^{\circ} \mathrm{C}$ for 7 days. Slow decline in E.coli count was observed, where the E.coli strains survived till the end of the week and persisted in large numbers $\left(3.7 \times 10^{5}\right.$ cells $\left./ \mathrm{ml}\right)$ and resisted the acidity of $\mathrm{pH}$ 4.03. Public health hazard of yoghurt contamination with such E.coli strains was discussed. An experiment was carried out to study the probability of plasmid transmission from E.coli strains to starter organisms. Yoghurt was prepared from two types of starters. One of them lived and stored with the tested E.coli strain and the other was clean starter. Minimum inhibitory concentrations of unasyn, cephradin, claforan and cloxacillinwhich showed resistance against the tested E.coli strain- were added to sterile milk after inoculation of the two types of starters separately. The obtained data declared that E.coli plasmids could not be transmitted to the starter organisms, also, the results were discussed.
\end{abstract}

\section{INTRODUCTION}

The main object in terms of food hygiene is to avoid risks resulting from the presence of either pathogenic, potentially pathogenic or toxogenic organisms in food (Pazakova et al.,
1997) rather than its devoiding of any microorganisms carry antibiotic resistance genes (plasmids) as these plasmids may be transmitted to other human intestinal commensal flora (Wagner and Hahn, 1999). 
The multidrug resistance organisms even those which are non pathogenic may constitute reservoirs for disseminating antibiotic resistance plasmids to other pathogens in the community (Kessie et al., 1998). Subsequently, Stephan and Schumacher (2001) recommended periodic surveillance of antibiotic resistance testing for both pathogenic and non pathogenic bacteria in humans, livestocks, foodstuffs and environments to detect the emergence of these resistant genes among different bacterial species. They added that simillar plasmids which carry the same antibiotic resistance patterns establish the genetic exchange between strains living in a close vicinity.

Furthermore, non pathogenic microorganisms may pass from animals to humans via food products and when they are carrying transconjugative plasmids, the latter may be transferred to pathogenic or indigenous flora of human body (Moro et al., 1998). It was found that the coagulase negative staph.spp. of human which are known to be non pathogenic but opportunistic organisms may become a serious problem when they express gene encoded antibiotic resistance (Bagado et al., 2001).

Contamination of dairy products by Escherichia coli has been used for a long time as an index of fecal pollution and unsanitary manufacturing or handling practices and their growth in such products may be responsible for defects in texture and flavour (Ernstorm, 1954). However, since the implication of certain strains of E.coli in several cases of foodborne illness outbreaks (Marier et al., 1973), the presence of E.coli in the dairy products has become of a public health hazard. Several studies have been conducted to characterize Enteropathogenic E.coli (EEC) and E.coli 0157:H7 in fermented skim milk and yoghurt (Goel et al., 1971; Frank and Marth, 1977;
Prasad et al.,1980; Mohanan et al., 1985; Ahmed, 1990 and El-Hawary and Aman, 1998).

This study was planned to evaluate the growth and fate of non pathogenic $E$. coli strain isolated from subclinical mastitic milk samples) which was carrying plasmids encoding multidrug resistance during the manufacture and storage of yoghurt and its public health hazard. Also to study the probability of transferring of plasmids encoding multidrug resistance from the inoculated E.coli strain to the yoghurt starter cultures.

\section{MATERIAL AND METHODS :}

\section{1- E.coli isolates:}

E.coli strains were isolated from milk samples of subclinical mastisis affecting Friesian Holstein cows. Isolation and identification of E.coli was carried out according to the method recommended by Quinn et al. (1994). The E.coli isolates were subjected to serotype identification using nine available antisera (O:26ab, 0:55, 0:86a, 0:111, O:119, O: 124, O: 125 ac, O:126 and O:128) produced by (Difico) and following the manufacturer instructions.

\section{2-Antimicrobial susceptibility testing:}

It was carried out using disc diffusion method on nutrient agar plates against 13 antimicrobial agents (cefobid, $75 \mu \mathrm{g}$, ofloxacillin $100 \mu \mathrm{g}$, caloforan $30 \mu \mathrm{g}$, streptomycin $10 \mu \mathrm{g}$, spiramycin $100 \mu \mathrm{g}$, cephardine $30 \mu \mathrm{g}$, cloxacillin $5 \mu \mathrm{g}$, ampicillin 10 $\mu \mathrm{g}$, unasyn $30 \mu \mathrm{g}$, amoxicillin $10 \mu \mathrm{g}$, penicillin $10 \mu \mathrm{g}$, ciprocin $5 \mu \mathrm{g}$ and polymexin B-sulphate 300 IU - Oxoid limited- England \& UCCMAEgypt.).

Judgement and categorizing for susceptibility were based on diameter of 
inhibition zone measurements and according to Beuer-Kirby scale (Atlas, 1995).

\section{3- Plasmid profile analysis:}

Screening the existance of plasmid DNA in E.coli strains was done by the alkaline lysis technique. The extracted DNA for each strain was subjected to electrophoresis running through $0.7 \%$ agarose gel stained by ethiolium $0.5 \mu \mathrm{g} / \mathrm{ml}$ gel and running $100 \mathrm{~A}-120 \mathrm{~V}$. with marker of E.coli V. 517 according to David et al. (1991).

\section{4- Survival of E.coli in yoghurt: a-Culture:}

An untypable E.coli strain, recovered from a subclinical mastitis milk sample which was characterized by multidrug resistant pattern against eight antimicrobial agents (ampicillin, unasyn, penicillin G, calforan, spiramycin, cephradin and cloxacillin) and also was carrying four plasmids with molecular sizes 5.3, 5.5, 7 and $7.5 \mathrm{~Kb}$ - (Fig. 1) was selected to be inoculated into sterile milk used for yoghurt manufacture. The test organism was grown in brain heart infusion broth (Oxoid), and incubated at $37^{\circ} \mathrm{C}$ for $24 \mathrm{~h}$. Starter cultures (Streptococcus thermophilus and Lactobacillus bulgaricus) grown in sterile skim milk were obtained from the department of Food Science, Faculty of Agriculture, Assiut University.

\section{b-Preparation and sampling of youghurt:}

Two lots of yoghurt were prepared from sterile milk. The milk was inoculated with starter cultures according to Lampert (1975), and divided into two portions. The first portion was inoculated with the test organism (E.coli) to provide $1.3 \times 10^{7}$ cells $/ \mathrm{ml}$. The other portion was taken as a control (free from $E$.coli). The two lots of milk were incubated in an adujustable water bath at $37^{\circ} \mathrm{C} \pm 1^{\circ} \mathrm{C}$ to allow a slow fermentation and production of yoghurt. The infected yoghurt and its control were kept in a refrigerator at $4^{\circ} \mathrm{C} \pm 1^{\circ} \mathrm{C}$. To determine E.coli count and pH value, Samples were taken from milk after inoculation, from prepared yoghurt and daily thereafter up to 7 days. The samples were prepared for examination according to standard methods (A.P.H.A, 1978).

\section{c- Enumeration of E.coli:}

The method suggested by Speck et al. (1976) was employed. Samples were surface plated onto trypticase soy agar (Oxoid).The plates (duplicate plates for each dilution) were held for one hour at room temperature followed by adding a layer of violet red bile agar (Oxoid), then were incubated at $37^{\circ} \mathrm{C}$ for 24 hours.

\section{d- pH detemination:}

The pH value of milk and yoghurt was determined by using pH meter Jenway model 350 supplied with standard combination electrod.

5-Assessment of plasmids (encoding multidrug resistance) transference from E.coli into starter cultures of yoghurt:

Two lots of sterile milk were prepared. The first lot was inoculated with a culture from yoghurt previously infected with $E$.coli carrying plasmids encoded multidrug resistance and stored for 7 days. Then the milk was divided into four portions; each of them was inoculated with the minimum inhibitory concentration (MIC) of specific antibiotics; unasyn (16 $\mu \mathrm{g})$, claforan $(6.25 \mu \mathrm{g})$, cloaxacillin $(12.5 \mu \mathrm{g})$ and cephradine $(6.25 \mu \mathrm{g})$ according to National Committee of Clinical Laboratory Standards (Nccls, 1993). The second lot of the sterile milk 
was inoculated with a starter culture of yoghurt free from the test organism (E.coli), and then the milk was divided into four portions, each was prepared to contain the same concentrations of the specified antibiotics as mentioned above. The eight portions of milk were made yoghurt according to Lampert (1975). A control yoghurt was prepared from a sterile milk free from added antibiotics for each type of starter culture used.

\section{RESULTS :}

The results were recorded in Tables $(1 \& 2)$ and Fig. (1).

Table (1): Survival of untypable E.coli carrying multidrug resistance plasmids in yoghurt during its preparation at $37^{\circ} \mathrm{C}$ and storage at $4 \pm 1^{\circ} \mathrm{C}$.

\begin{tabular}{|c|c|c||}
\hline Days of storage & $\begin{array}{c}\text { Count of } \\
\text { E.coli/gm }\end{array}$ & $\begin{array}{c}\text { pH } \\
\text { value }\end{array}$ \\
\hline inoculum of milk & $1.3 \times 10^{7}$ & 6.6 \\
\hline $\begin{array}{c}\text { 0 time } \\
\text { (Finished product) }\end{array}$ & $3.2 \times 10^{6}$ & 5.24 \\
\hline 1 & $3 \times 10^{6}$ & 4.40 \\
\hline 2 & $2.7 \times 10^{6}$ & 4.20 \\
\hline 3 & $2 \times 10^{6}$ & 4.15 \\
\hline 4 & $1 \times 10^{6}$ & 4.15 \\
\hline 5 & $6 \times 10^{5}$ & 4.10 \\
\hline 6 & $6 \times 10^{5}$ & 4.03 \\
\hline 7 & $3.7 \times 10^{5}$ & 4.03 \\
\hline
\end{tabular}

Table (2): Production of yoghurt from milk containing minimum inhibitory concentration (MIC) of the selected antibiotics.

\begin{tabular}{|l|l|c||}
\hline \multicolumn{1}{|c|}{ Milk used } & \multicolumn{2}{|c||}{ Yogurt production } \\
\cline { 2 - 3 } & Starter A* & $\begin{array}{c}\text { Starter } \\
\text { B** }\end{array}$ \\
\hline $\begin{array}{l}\text { I- Added antibiotics: } \\
\text { Cloxacillin } 16 \mu \mathrm{g} / \mathrm{ml} \\
\text { Cifradine } 6.25 \mu \mathrm{g} / \mathrm{ml} \\
\text { Claforane } 6.25 \mu \mathrm{g} / \mathrm{ml}\end{array}$ & $\begin{array}{l}\text { failed } \\
\text { failed } \\
\text { failed } \\
\text { failed }\end{array}$ & $\begin{array}{c}\text { failed } \\
\text { failed } \\
\text { failed } \\
\text { failed }\end{array}$ \\
\hline $\begin{array}{l}\text { II- Antibiotic free } \\
\text { sterile milk }(\mathrm{Control})\end{array}$ & + Ve & + Ve \\
\hline *Starter A: a starter culture previously lived and stored with \\
the tested E.coli strains carrying multidrug resistance \\
plasmids. \\
**Starter B: Clean starter culture.
\end{tabular}

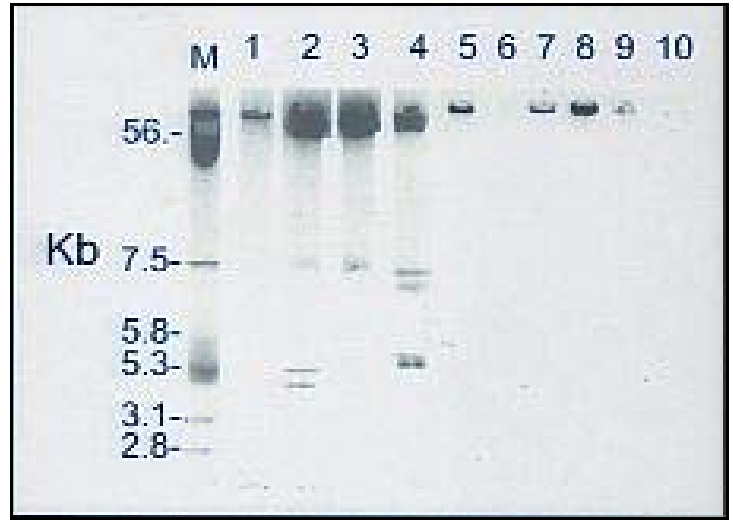

Fig. (1): Plasmid profile analysis of multidrug resistance E.coli strains recovered from bovine subclinical mastitis.

\section{DISCUSSION :}

In recent years, there is an alarming increase in the rate of human infections with antibiotic resistant microorganisms (Salvat et al. 2001). Two main categories of bacteria carrying genes encoding for antibiotic resistance may be transmitted from animals to humans via food products. The first category is the obligate infectious pathogens as Salmonella enterica, while the second one is the facultative pathogenic species as E.coli (Wagner and Hahn, 1999), the matter we concerned in the present work. The public health hazard of E.coli strains when they are present in human gut is manifested not only in being faculatative pathogens, but also in disseminating their multidrug resistance plasmids and infecting other microorganisms since the transference of these plasmids can take place and the exchange may occur even between gram +ve and gram ve bacteria through conjugational genetic transfer (Mazodier and Davis, 1991 and Kessie et al., 1998).

\section{1-Antimicrobial susceptibility and plasmid profile analysis:}


The obtained results proved that E.coli strains recovered from bovine subclinical mastitis were untypable as they are negative for serotype reactions against the nine available antisera. Through screening of plasmid existance, only four strains out of ten multidrug resistant E.coli were carrying plasmids with molecular sizes ranged from 5.3-7.5 kilo base pairs (kb)- (Fig.1). The highly antibiotic resistant strains carrying no plasmids indicated that the encoding genes were located chromosomally giving rise to perminant non transferable high level of resistance (Thomas et al., 1999). E.coli strain No. 4 was selected for yoghurt inoculation process which was multidrug resistant carrying four plasmids (Fig.1).

\section{2- Survival of E.coli in yoghurt :}

As recorded in Table (1), $E$. coli decreased in numbers from $1.3 \times 10^{7}$ to $3.2 \times 10^{6}$ cells/ ml during preparation of yoghurt (at $\left.37 \pm 1^{\circ} \mathrm{C}\right)$. The organism began to lose its viability very slowly during refrigerated storage at $4 \pm 1^{\circ} \mathrm{C}$ and reached a minimum of $3.7 \times 10^{5}$ cells $/ \mathrm{ml}$. The data in Table (1) indicated that there was no significant change in the number of E.coli during the 96 hours following yoghurt preparation. The numbers began to decrease slowly during the storage, and the organism survived until the end of the week at a population of $3.7 \times 10^{5}$ cells $/ \mathrm{ml}$.

There was a slow drop in the $\mathrm{pH}$ value of yoghurt during its preparation and storage to reach its minimum value (4.03) by the end of the week. No significant changes in the $\mathrm{pH}$ value of yoghurt during the $3^{\text {rd }}, 4^{\text {th }}$ and $5^{\text {th }}$ day were observed

It is obvious from the obtained results (Table 1) that E.coli could survive until the end of 7 days and existed in large numbers $\left(3.7 \times 10^{5}\right.$ cells/ml) however, the $\mathrm{pH}$ value was unfavourable. This could be explained on the fact that the low fermentation temperature $\left(37^{\circ} \mathrm{C}\right)$ used for preparation of yoghurt allows slow production of lactic acid which may creat the opportunity for the organism to adapt such acid medium. Also, the survival of such organism could be attributed to the nature of the strain used which may had the ability to resist acid medium. Such phenomenon was observed by Gibson et al. (2002) who proved that E.coli 0157 could survive and increased in numbers in yoghurt prepared at temperature below $40^{\circ} \mathrm{C}\left(25-37^{\circ} \mathrm{C}\right)$ despite the continued decline in acidity of milk. Also, they found that when yoghurt prepared at temperatures ranged from $40-43^{\circ} \mathrm{C}$, E.coli 0157 died quickly and could not be detected by the end of storage (4 days) at $4^{\circ} \mathrm{C}$. Ahmed (1990) obtained different results and proved that Enteropathogenic E.coli $0125 / B 15$ survived in yoghurt kept at $5 \pm 1^{\circ} \mathrm{C}$ for ten days and could not be detected by the end of storage $(<10 / \mathrm{ml})$. Furthermore, ElHawary and Aman (1998) stated that E.coli 0157:H7 could survive in yoghurt for 9 days reaching to a minimum count of 40 cells $/ \mathrm{ml}$ and the organism failed to recover by the end of the $11^{\text {th }}$ day. The variation in such results could be attributed to many factors including nature of the strain used, temperature of initial incubation (during preparation), storage temperature which may control multiplication of the organism but the inoculation dose at storage is quite important.

The obtained results indicated that the fermentation acids were not effective against such E.coli carrying multidrug resistance plasmids and could posses a potential health hazard. It has been stated that antibiotic resistant non pathogenic organisms in an animal may be passed to, and colonize humans carrying R-plasmids (transmissible) into 
human environment. These R-plasmids may subsequently be transferred to human pathogens or flora (Levey 1992). Their transamission via food products and their zoonotic importance were established and widely discussed (Singh et al.,1992 \& Wagner and Hahn 1999).

\section{3-Assessment of plasmids (encoding} multidrug resistance) transference from E.coli into starter culture of yoghurt:

As shown in Table (2), yoghurt failed to be produced from sterile milk containing the added MIC of the tested antibiotics either by using starter cultures lived with E.coli carrying multidrug resistance plasmids or by using clean yoghurt starter culture. Fortunately, these results indicated that E.coli strains failed to infect starter cultures of yoghurt with such plasmids. The failure of plasmid transference may be attributed to the very small molecular sizes of plasmids carried by the tested E.coli strain $(5.3-7.5 \mathrm{~kb})$ as the smallest conjugative plasmids in Enterobacteriaceae detected to be transferred are about 30 kb (Scott, 1984; Thomas and Smith, 1987 and Bennett \& Howe, 1998). Also, it has been stated that the plasmids can be transferred between strains of the same species and between strains of different species, whereas the frequency of transfer is reduced in fusion between different species somewhat from that of intraspecific fusion (Bennett \& Howe, 1998).

In conclusion, contamination of yoghurt or other dairy products by E.coli from the view point of public health should not be ignored. The development of populations of E.coli with transmissible drug resistant plasmids in food posses a potential threat to public health. Also, it is concluded that fermentation acids are not effective against the drug-resistant E.coli, therefore if pasteurized milk is contaminated with such organism, the fermented products posses a potential health risk.

\section{REFERENCES :}

1-A.P.H.A. (1978): Standard Methods for the examination of Dairy products. E. H. Marth (ed), 14th edition, A.P.H.A., Wasington, D. C.

2-Ahmed, A, AH. (1990): Prevalence and survival of enteropathogenic Eschechia coli (EEC) in yoghurt. Assiut Vet Med. J. Vol. 22, (44): 95-100.

3-Atlas, R.M. (1995): Principles of Microbiology. pp. 364-365. Mosby Year book Inc. 1 st ed. USA.

4-Bagado, I.; Sutich, E.; Krapp, A.; Marchiaro, P.; marzi, M.; Putero, J. and Carrillo, N. (2001): Methicillin resistance study in clinical isolates of coagulase-negative staphylococci and determination of their susceptibility to alterative antimicrobial agents. Journal of Applied Microbiology 91, (4): 344-350.

5-Bennett, P. M. and Howe, T. G. (1998): Plasmids; Bacterial and bacteriophage genetics in: Topley and Wilson's microbiology and microbial infections Vol. (2): Systemic Bacteriology the 9th ed. Arnold, Greet britain 251-260.

6-David, B.P.; Purushothaman, V. and venkales, R.A. (1991): Comparison of plasmid profile analysis, antibiogram testing, resistotyping and biotyping in identification of Esherchia coli isolates. Vet. Rec. Aug. 3; 129 (5): 94-97.

7-El-Hawary, I. I. and Aman, I. M. (1998): Survival charactersistics of Escherchia coli 0157:H7 in ice cream and yoghurt. 8 th Sci. Cong. 15-17 Nov. 1998, Fac. of Vet. Med., Assiut, Egypt.

8-Ernstrom, C. A. (1954): An early gas defect in pasteurized milk Cheddar cheese. Milk Prod. 
J. 45: 21, 42 (Cited after Frank and Marth, 1978).

9-Frank, J. F. and Marth, E. H. (1977): Inhibition of Enteropathogenic Escherchia coil by homofermentative lactic acid bacteria in skim milk. I. comparison of strains of Escherchia coli. J. Food Prot. 40(11), 749-753.

10-Gibson, H.; Hill, D. and Whitehead, M. (2002): Control of acid resistant Escherchia coli in milk fermentations. (personal communication). Wolver Hampton University (WVL) United Kingdom.

11-Goel, M. C.; Kulshrestha, D. C.; Marth, E. H.; Francis, D. W.; Bradshaw, J. G. and Read, R. B.Jr. (1971): Fate of coliforms in yoghurt, butter milk, sour milk and cottage cheese during refrigerated storage. J. Milk Food Technol. 34: 54-58.

12-Kessie, G.; Ettayebi, M.; Haddad, A.M.; Shibl, A. M.; Al-Shammary, F. J.; Tawfik, A. F. and Al-Ahdal M. N. (1998): Plasmid profile and antibiotic resistance in coagulase negative staphylococci isolated from polluted water. Journal of Applied Microbiology, 84,(6):417422.

13-Lampert, L.M. (1975): "Modern dairy products 3 rd edition. Chem Publ. Co., Inc. New York. pp 227-229.

14-Levey, S. B. (1992): The antibiotic paradox: How miracle drugs are destroying the miracle. New York Plenum Press. 1 st Ed.

15-Marier, R.; Wells, J. G.; Swanson, R. C.; Caflahan, W. and Mehlman, I. (1973): An outbreak of Enteropathogenic Escherchia coli foodborn disease traced to imported French cheese. Lancet 2: 1376-1378. (Cited after frank and Marth, 1978).

16-Mazodier, P. and Davis, J. (1991): Gene transfer between distantly related bacteria. Annu. Rev. Genet, 25: 147-171.

17-Mohanan, K.R.; Shankar, P.A.; Laxminarayana, H. (1985): Growth and survival of microbial contaminants in dahi. Indian Journal of Dairy Science. 38 (3), 208-216.

18-Moro, M. H.; Beran, G. W.; Hoffman, L. J. and Griffith, R. W. (1998): Effects of cold stress on the antimicrobial drug resistance of Escherchia coli of the intestinal flora of swine. Letters in Applied Microbiology, 27,(8): 251254.

19-National Committee for Clinical Laboratory Standard (NCCLS) (1993): methods for dilution antimicrobial susceptibility tests for bacteria that grow aerobically. Approved Standard No. M7-A3 2nd ed. NCCLS, Wayne, P. A. USA.

20-Pazakova, J.; Turek, P. and Laciakova, A. (1997): The survival of Staphylococcus aureus during the fermentation and storage of yoghurt. Journal of Applied Microbiolgy, 82 (5): 659-662.

21-Prasad, G.; Khan, B. L.; Kulshrestha, D.C. (1980): Survival of Escherchia coli and Enterobacter aerogenes in dahi. I- Contamination of milk before preparation of dahi. Indian J. of Dairy Science, 33 (4), 497-500.

22-Quinn, P.J.; Carter, M.E.;Karkey, B.K.; and Karter, GR. (1994): Clinical veterinary Microbiology year book Europe limited $1^{\text {st }}$ ed. 23-Salvat, A.; Antonnacci, L.; Fortunato, R. H.; Suarez, E.Y. and Godoy, H.M. (2001): Screening of some plants from Northen Argentina for their antimicrobial activity. Letters in applied microbiology, 32(1): 293297.

24-Scott, J. R. (1984): Regulation of plasmid replication. Microbiol. Rev. 48: 1-23.

25-Singh, M.; Sanyal, S. C. and Yadav, J. N. (1992): Enterotoxigenic drug resistant plasmids in animals isolates of Escherichia coli and their zoonotic importance. J. Trop. Med. Hyg., 95 (5): 319-321.

26-Speck, L. M. (ed.) (1976): Compendium of methods for microbiological examination of food. A. P. H. A., Washington, D. C. 
27-Stephan, R. and Schumacher, S. (2001): Resistance patterns of non-O157 shiga toxinproducing Escherchia coli (STEC) strains isolated from animals, food and asymptomatic human carriers in Switzerland. Letters in Applied Microbiology, 32, (11): 114-117.

28-Thomas, C. M. and Smith, C. A. (1987): Incompatibility group $P$ plasmids: genetic, evolution, and use in genetic manipulation. Annu. Rev. of Microbiol., 41: 77-101.
29-Thomas, D. G.; Wilson, J. M.; Day, M. J. and Russell, A. D. (1999): Mupirocin resistance in staphylococci: development and transfer of isoleucyl-t RNA synthetasemediated resistance in vitro. journal of Applied Microbiology, 86 (4): 715-722.

30-Wagner, J. and Hahn, H. (1999): Increase of bacterial resistance in human medicine by resistance genes of bacteria from meat supplying animals. Berl. Munch. Tieraztl Wochenschr, 112 (11): 380-384.

$$
\begin{aligned}
& \text { نمو وبقاء ميكروب الايشيريشيا كولاى الحامل للبلازميدات الخاصة }
\end{aligned}
$$

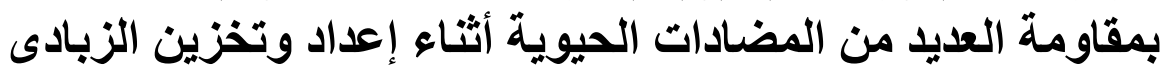

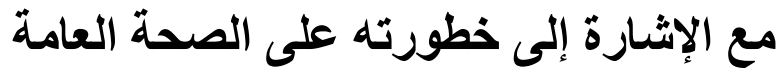

$$
\begin{aligned}
& \text { محمد محمد عبد الحفيظ ، آمال على عبد الحليم }
\end{aligned}
$$

بفحص عينات من لبن أبقار مصابة بالتهاب الضرع الخفى تم عزل عترات من ميكروب الايشيريشيا كولاى وتم تصـنيفها بيوكيميائيـا ويفحصـها سـيرولوجيا باسـتخدام 9 مسن مضـاد الأمصـال المتاحـة تبـين أنهـا غيـر مصـنفة سيرولوجيا. وكذلك تم إجراء اختبـارات الحساسية لعدد r ا مضـاداً حيويـاً (سيفوبيد، اوفلوكساسيللين، كلافوران، ستريتومايسـن، سبيراميسـين، سـيفرادين، كلوكساسـيللين، أمبيسـلين، يوناسـين، أموكسيسـيلين، بنسـلين ج، سييروسين، بوليمكسين ب سـلفات). وتم اختبـار عشرة عترات من هذه الميكرويـات لها المقاومـة المتعددة لهذه المضـادات الحيويـة وذلك لاستقصـاء وجود البلازميدات الخاصـة بها وياستخدام التحليل الاكتروفوريسـى تبين أن أربعة منها كاتت تحمل بلازميدات متعددة. وقد اختلفت أحجامها الجزئية وترواحت من ب، ه - V،0 كيلوبيز بيز

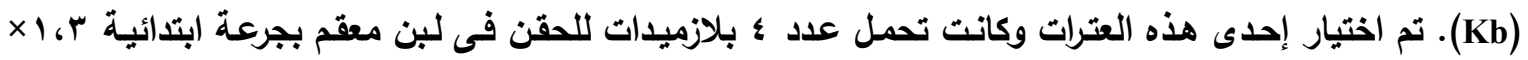

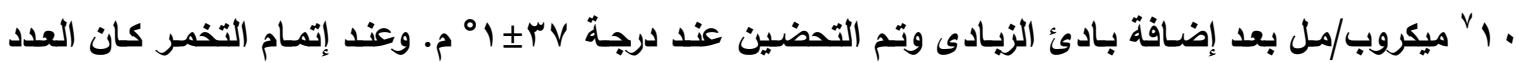

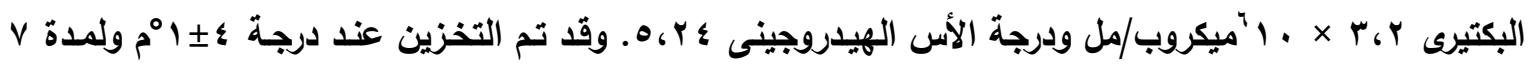

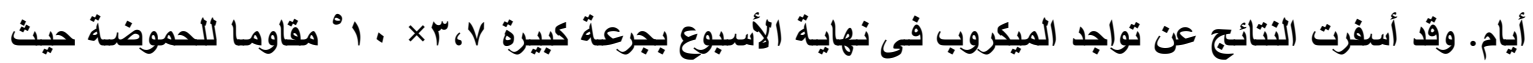
بلغ الأس الهيدرجينى حينئ ب ، ، ع ، ولقد تمت مناقشة مدى خطورة تواجد هذه الميكرويـات الحاملة للبلازميدات فـى الزبـادى ومنتجـات الألبـان على الصـحة العامـة للإنسـان. ولدراسـة مـدى احتمـال انتقـال بلازميـدات المقاومـة البكتيرية للمضادات الحيوية إلى ميكروب البادئ تم إجراء تجرية إعداد زيادى من بادئات جديدة ، وكذلك من بادئات الزبـادى المصـابة بميكروب العترة المختبرة فى ألبان معقمـة مضـافا إليها جرعـات مـن بعض المضــادات الحيويـة 
المقاوم لها العترة المختبرة (يوناسين، سيفرادين، كلافوران، كلوكساسيللن) بأقل جرعة مثبطة كل على حدة .

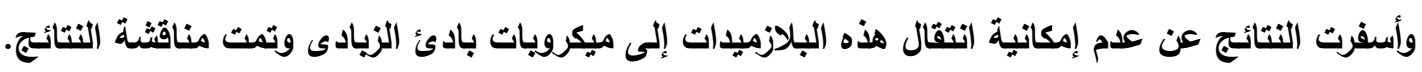

